\title{
Business Model Innovation from an Business Model Ecosystem Perspective
}

\author{
Peter Lindgren* and Jesper Bandsholm
}

\author{
Aarhus University, Department of Business Development \& Technology, \\ Birk Centerpark 15, 7400 Herning, Denmark \\ E-mail: \{peterli; bandsholm\}@btech.au.dk \\ *Corresponding Author
} Received 1 September 2016; Accepted 20 October 2016;
Publication 25 November 2016

\begin{abstract}
This paper deals with the perspective of business model ecosystem-thinking in relation to business model innovation and shows the importance of taking the business network and business model ecosystem into consideration when trying to operate and develop business models. The paper verifies that "No business is an island" and neither are business models and therefore they can't be treated like this. This paper also introduce another perspective upon the business model ecosystem (BMES) approach - as a way of thinking business model innovation - using a case related to renewable energy from an island called Sams $\varnothing$ in Denmark, that has developed in relation to the EU Interreg project Biogas2020.
\end{abstract}

Keywords: Business Model Ecosystem, Business Model Innovation, Ecosystem, Network.

\section{Introduction to Business Model Ecosystem}

A lot of research has been done within Business Models (BM) and Business Model Innovation (BMI) (Amit \& Zott, 2001; Chesbrough \& Rosenbloom, 2002; Christensen \& Raynor, 2003; Govindarajan \& Trimble, 2005;

Journal of Multi Business Model Innovation and Technology, Vol. 4_2, 51-70.

doi: $10.13052 /$ jmbmit2245-456X.422

(c) 2016 River Publishers. All rights reserved. 


\section{P. Lindgren and J. Bandsholm}

Markides \& Charitou, 2004; Markides, 2008; Zott, 2011; Teece, 2010; Teece 2011 ) and stated the emphasis and relevance of this in the modern world with short development times and business model lifecycles (Lindgren \& Abdullah, 2013).

This has led to an increased focus upon open business model innovation (Chesbrough, 2002 and 2006), open business models (Lindgren, 2013). Open business models can take status of different set ups as referred to in Figure 1.

Collaboration in networks of business models in order to stay cope with the development in the BMES and ensure the competitiveness and sustainability of the business hereby gets very important.

This paper aims to elaborate upon this field of research by taking a step back and look deeper into term BMES defined as (Lindgren 2016):

"A BMES is representing more business models from more businesses"

"A business is seldom represented in just one BMES, but is more often represented by different BM's in more BMES"

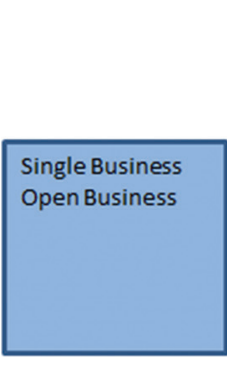

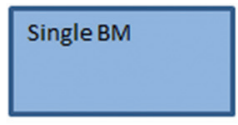

Inside existing BM

Inside existing Business

Inside or outside exsting BM

Inside or outside existing Business

Inside or Outside existing Network

Inside or outside existing Society

Inside or outside existing World

(Physical, digital and virtual world)

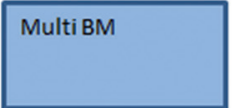

Inside existing BM

Inside existing Business

Lindgren 2011 Inspired by Chesbrough, Von Kroghen and Chanal and Caron-Fasan

Figure 1 Different contexts of open business model constructions Lindgren 2011. 
as illustrated in Figure 2.

Figure 2 shows a model of value flow in different viewpoints of a BMES,

Quadrant 1 - Internal the individual BMES - A part of a BM's value flow inside a BMES - example difrerent Business BM value flow in Wind Mill BMES.

Quadrant 2 - BMES's vertically related - BMES related as suppliers and customers to each other in an "upstream" and "down stream" value flow - example BMES value chain (Energy BMES's - coal BMES to electricity BMES to household BMES).

Quadrant 3-BMES's horizontally related-BMES related as "colleges" in related BMES - example (oil-, gas-, solar-, electricity in energy production).

Quadrant 4 - BMES's not related - BMES's that are not related to and do no value exchange. Wind Mill BMES and Circus BMESTo accommodate the open and network oriented practitioner approach to BMI and the BMES approach, we set up the following research question:

"How to utilize your business model ecosystem related to open business model innovation to enhance business performance and locate opportunities?"

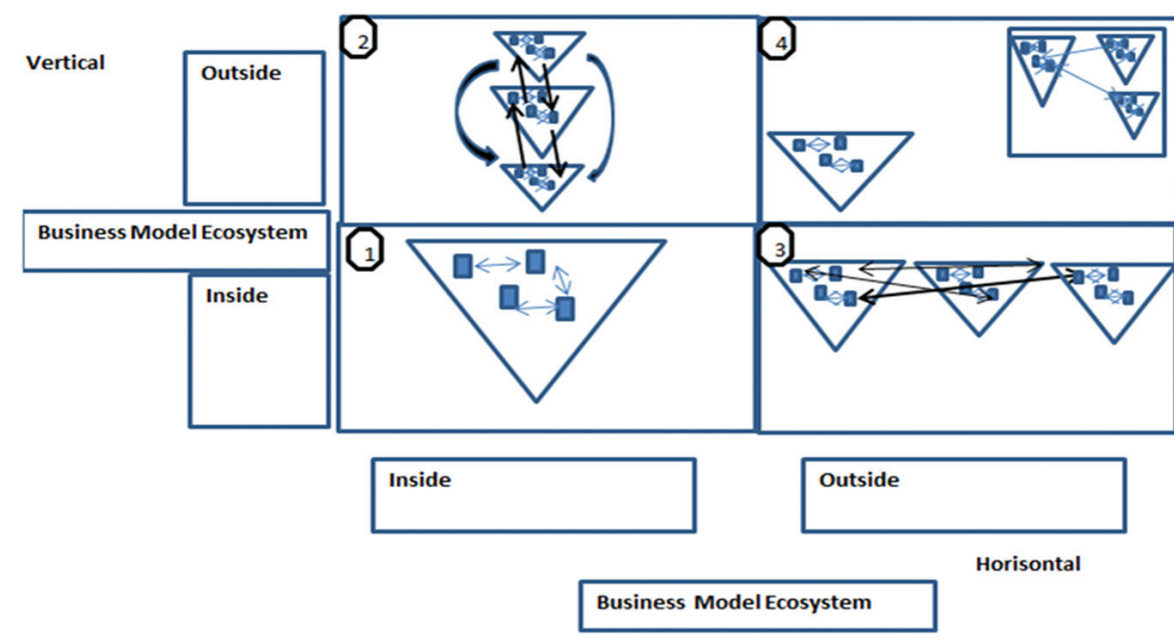

Figure 2 BMES Relationship Axiom (Lindgren 2016) inspired by Lindgren and Horn Rasmussen 2013. 


\section{The Business Model Ecosystem Related to Open Business Model Innovation}

A BMES can firstly be seen as a network of other businesses "As-Is" and "To-Be" BMs.

This means, that the further a business extend its view upon its BMES barriers - the context based approach to BMES - "view of a BMES", the weaker the link between the Businesses' core BM and the BM in the BMES will become. Opposite - following this approach - the larger potential to the business because the barriers or boarders of the business is not just limited to a specific market (Kotler 1984), Industry (Porter 1985), a cluster (Porter 1998) or in this case an island.

Therefore there is a hidden potential in these weak links, since they can become an important bridge for the business " $T o-B e$ " BM and realize needed BMES of this new BM or possible opportunities of BMES.

If we take a first look into the businesses' BMES (the upward pointing pyramid) and its relations to other BMs as seen in Figure 3.

The same BMES is the upward pointing pyramid on Figure 4, where it can be noticed the different BM layers inside a business. Each layer can be considered as a different level of business model innovation:

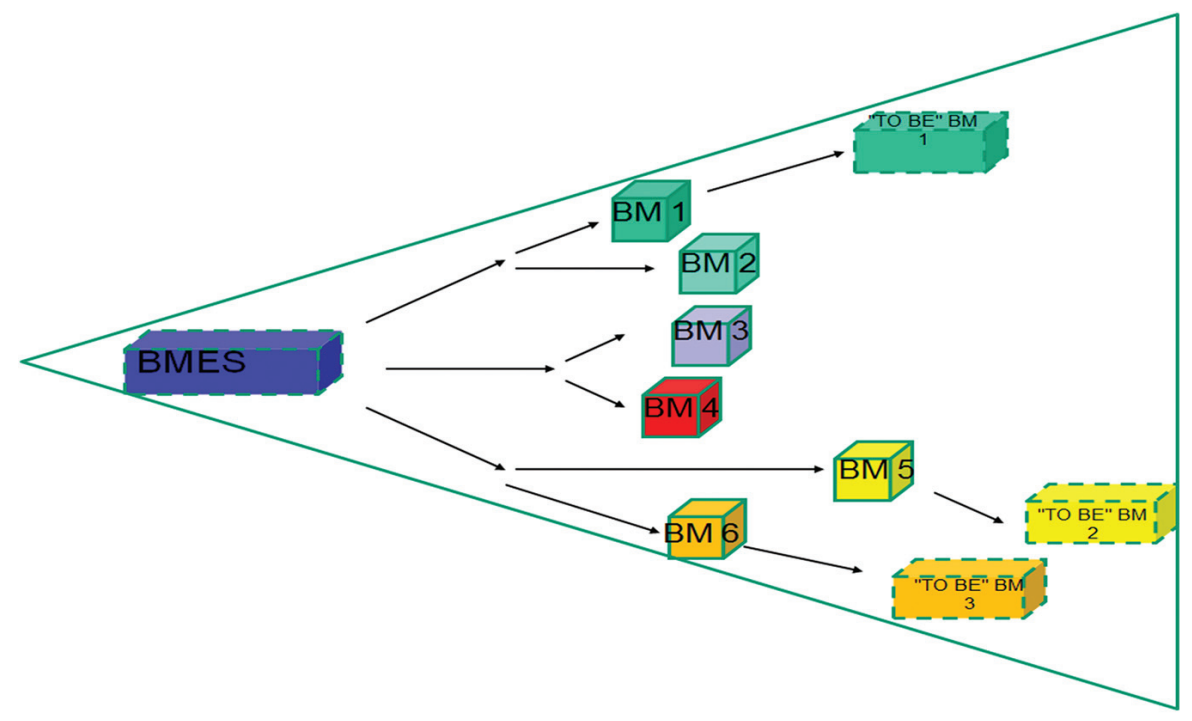

Figure 3 Lindgren 2016 the Multi Business Model approach related to a BMES. 

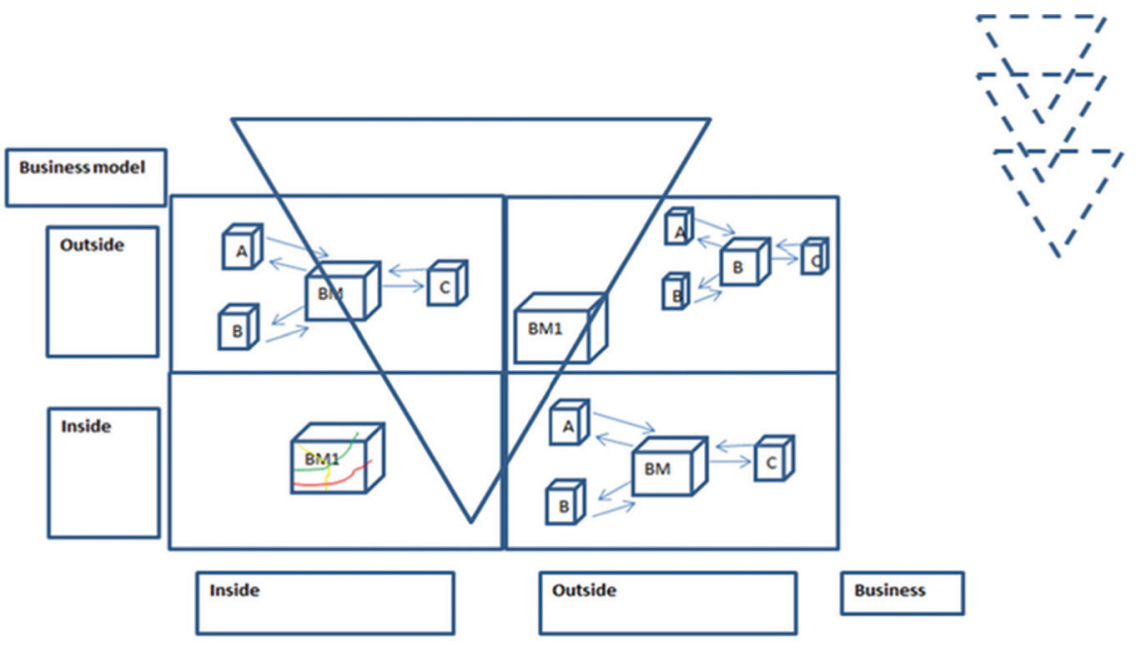

Figure 4 Business Models and Business Model Ecosystems.

Source: Lindgren and Horn Rasmussen 2012.

Table 1 Generic dimensions of a BMES

\begin{tabular}{|c|c|}
\hline Core Dimensions in a BMES & $\begin{array}{l}\text { Core Questions Related } \\
\text { to the Dimensions in a BMES }\end{array}$ \\
\hline $\begin{array}{l}\text { Value proposition/s (products, services } \\
\text { and processes) that the BMES offers } \\
\text { (Physical, Digital, Virtual) }\end{array}$ & $\begin{array}{l}\text { What value propositions do the BMES } \\
\text { provide? }\end{array}$ \\
\hline $\begin{array}{l}\text { Customer/s and Users that the BMES } \\
\text { serves - geographies, physical, } \\
\text { digital, virtual). }\end{array}$ & Who do the BMES serve? \\
\hline $\begin{array}{l}\text { Value chain functions [internal]. } \\
\text { (physical, digital, virtual) }\end{array}$ & $\begin{array}{l}\text { What value chain functions } \\
\text { do the BMES provide? }\end{array}$ \\
\hline $\begin{array}{l}\text { Competences (technologies, HR, } \\
\text { organizational system, culture) } \\
\text { (Physical, digital, Virtual) }\end{array}$ & What are the BMES competences? \\
\hline $\begin{array}{l}\text { Network - Network and Network } \\
\text { partners (strategic partners, suppliers } \\
\text { and others (Physical, digital, virtual) }\end{array}$ & What are the BMES networks? \\
\hline $\begin{array}{l}\text { Relations(s) e.g. physical, digital } \\
\text { and virtual relations }\end{array}$ & What are the BMES relations? \\
\hline $\begin{array}{l}\text { Value formula (Profit formulae } \\
\text { and other value formulae. } \\
\text { (physical, digital, virtual) }\end{array}$ & What are the BMES value formulae? \\
\hline
\end{tabular}

Source: The Business Model Ecosystem (Lindgren 2016). 
- The core business layer

Business Model Innovating on this layer means, that the business challenge the overall BM of its business, and will in many situations be considered a redefinition or even a turn-around for the business. Therefore, this will usually be tightly aligned with- and influenced by the overall business' strategy.

- BM Portfolio layer

If the business want to do BMI on this level, it will usually introduce, change and/or remove BM portfolios. The BM portfolio layer contains all the different BMs, that the business has - both those already in operation, "As-Is" BMs, and those in the making for the future, the "To-Be" BMs.

- BM Layer

Operating in this layer means, that you put your scope on a specific BM within your business. This layer makes you able to look deeper into and optimize or redefine a specific BM.

- BM Dimension layer

The dimension layers deals with the 7 dimensions within a BM (Lindgren \& Rasmussen, 2013). Here the business focus is on a specific dimension(s) and innovate upon that/those specific one(s).

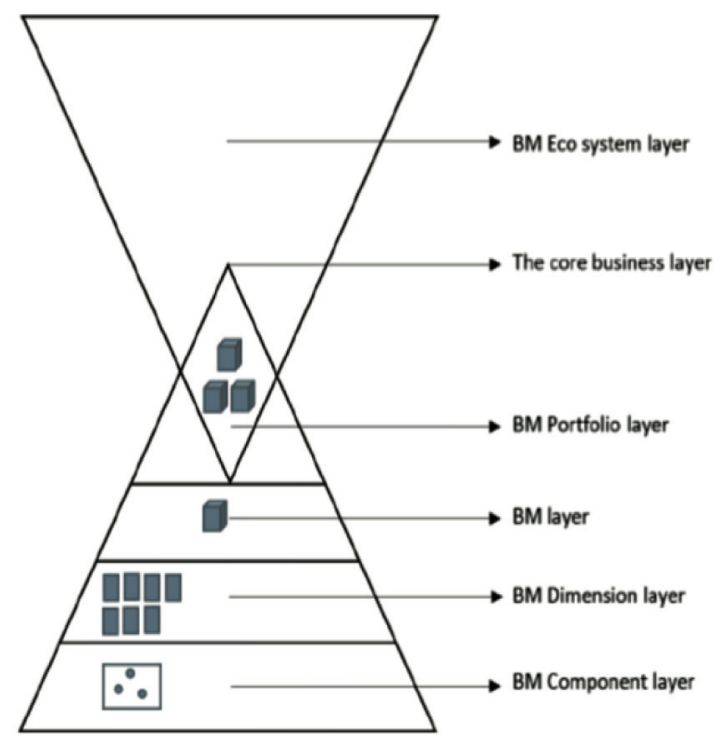

Figure 5 Business Model layers \& Business Model Ecosystem. 


\section{- BM Component layer}

This layer engages the deeper mechanisms within each of the BM dimensions - the components that makes up the dimension. This is considered as the most detailed layer of a BM and business model innovation that one can observe and engage with when observing and changing a BM and caring out BMI.

\section{The Samsø Biogas BMES and Samsø Biogas Business Case}

Sams $\varnothing$ is an island situated at the East of Jutland, Denmark.

The Sams $\varnothing$ island's economy has until now been based on high quality agriculture and farming. In the close future the residents, businesses, organizations of Sams $\varnothing$ agreed at an Open Space meeting, that the island should be fossil free by 2030 - an ambitious goal. (the island is looking for energy independence in an environmentally sustainable way. One of the most essential steps towards this goal is to ensure, that the nutrition and energy containing biomass is utilized. Due to this Sams $\varnothing$ want to develop a biogas plant, that can supply the islands' demand for fuel for among others the ferry to Jutland (Samsø Kommune 2015).

The "To-Be" BM project of making Sams $\varnothing$ fossil free is quite comprehensive - Figure X. This article deals with the implementation of a biogas plant relate to the BMES approach. This implementation will involve many different people and businesses on the island, who will be either directly or indirectly affected by the new biogas plant Figure 6. Technical drawing of TO BE Samsø BMES.

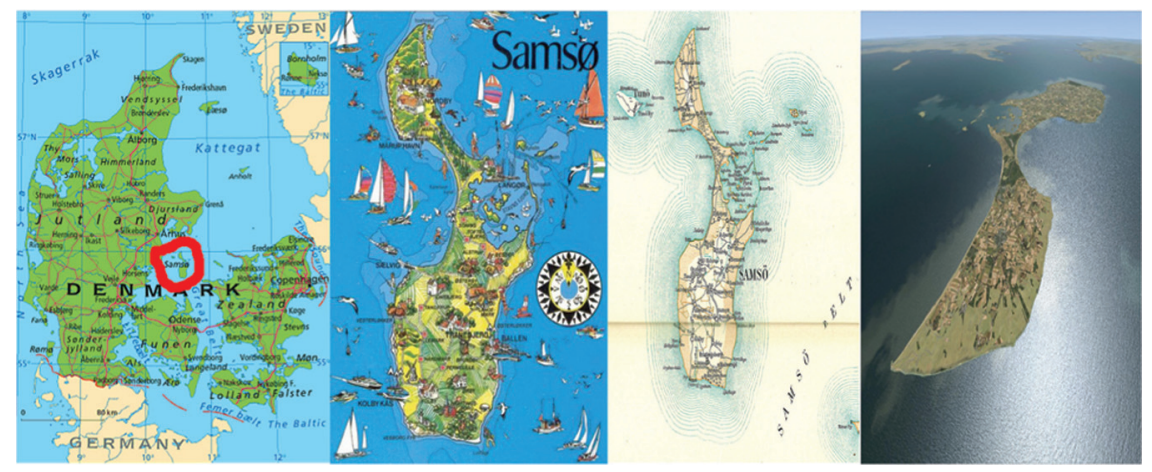

Figure 6 Sams $\emptyset$-different perspectives of the Island. 


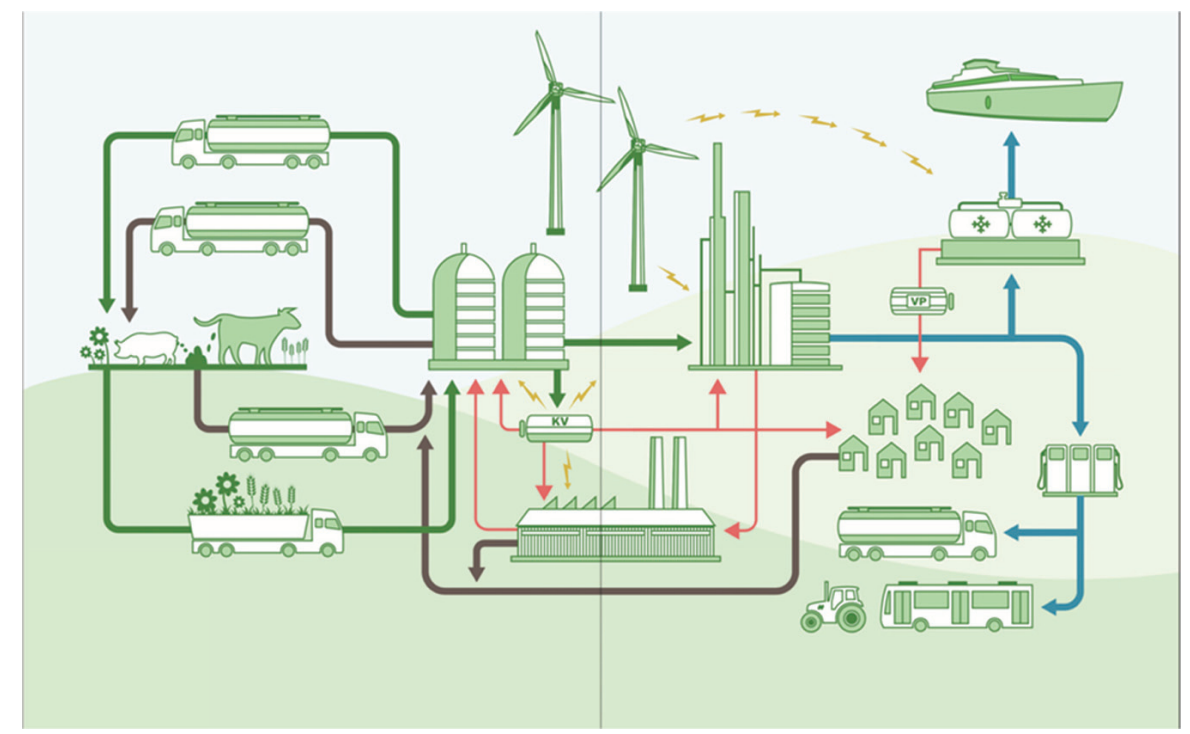

Figure 7 Samsø biogas ecosystem.

Source: Samsø Kommune 2015.

However, it will also affect businesses and business ecosystems outside Samsø.

We commence with the interaction between the farmers' BMs and the BM's of the biogas plant business. It is assumed, that the necessary calculations are made to ensure that the arguments for building a biogas plant - a new business - are present, and that the economical and value formula seems sound - The value formula (Lindgren 2013). These calculations are also being made to ensure, that Sams $\varnothing$ has the necessary amount of biomass available to produce enough biogas to the demand of the island. This should be done, to eliminate the risk of having a fully functional plant - but insufficient biomass to keep it running. This initiated biogas setup should also help the island to become fossil free within 2030 (Planenergi, 2015).

Similar to the above, the specific usage of the produced biogas will not be recommended in this report. However, there are many opportunities in biogas usage (Weiland, 2010), also on Sams $\varnothing$, such as

- Fuel for cars, busses, the ferries and agricultural machinery

- Possibilities in using the biogas for process- and district heating 


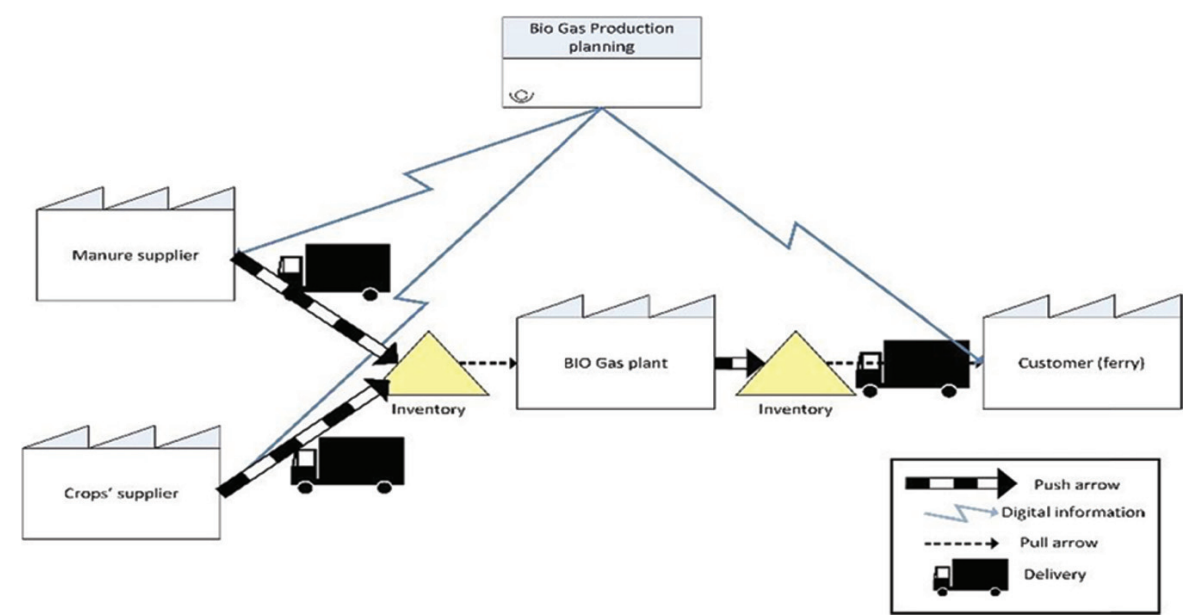

Figure 8 Sams $\emptyset$-different perspectives of the Sams $\emptyset$ biogas business setup related to network partners BM's on the Island of Samsø.

- Increase in activities in local construction businesses - building and maintenance of biogas plant and biogas infrastructure

- Equipment businesses in general.

\subsection{Biomass}

We commence to focusing on two overall types of biomass materials: manure from livestock primarily cattle and pigs at Sams $\varnothing$, and crops from farms, which come in a large variety at Sams $\varnothing$.

The composition of the available manure from livestock is well known IEA Bioenergy. (2012), A. M., F. N., Y. D., B. B., \& G. B. (2013) and it is easy to gain an overview of the availability of the manure at Sams $\varnothing$ as estimated and seen in Table 2. The manure, which is produced, will usually be used as fertilizer in the fields, but since the biogas production process actually increases the quality of the fertilizer, the aim of this BMES is to include as much manure as possible in the feedstock-mix of biomass into the biogas plant (Lantz et al., 2007). Not only does the quality of the fertilizing aspects of the manure increase due to the preprocessing, but additionally the smell is reduced and the useful nutrition and gasses are utilized in a more efficient way - seen from an environmentally sustainable perspective (Weiland, 2010).

A general production setup of biogas Sams $\varnothing$ business is shown in Figure 9. 
Table 2 Estimated annual manure production from farm animals on Sams $\varnothing$

\begin{tabular}{lrccc}
\hline & & & \multicolumn{2}{c}{ Biogaspotential (th.m $\mathrm{m}^{3} /$ year $)$} \\
\cline { 3 - 5 } Manure Type & $\mathrm{t} /$ year & Dry Matter $\%$ & $\mathrm{CH}_{4}$ & Biogas \\
\hline Cattle manure & 13.100 & 10,3 & 200 & 307 \\
Bedding & 5.000 & 30,0 & 225 & 346 \\
Pigs Manure & 33.300 & 5,3 & 380 & 585 \\
Total & 51.400 & 8,9 & 805 & 1.238 \\
\hline
\end{tabular}

Source: Planenergi 2015.

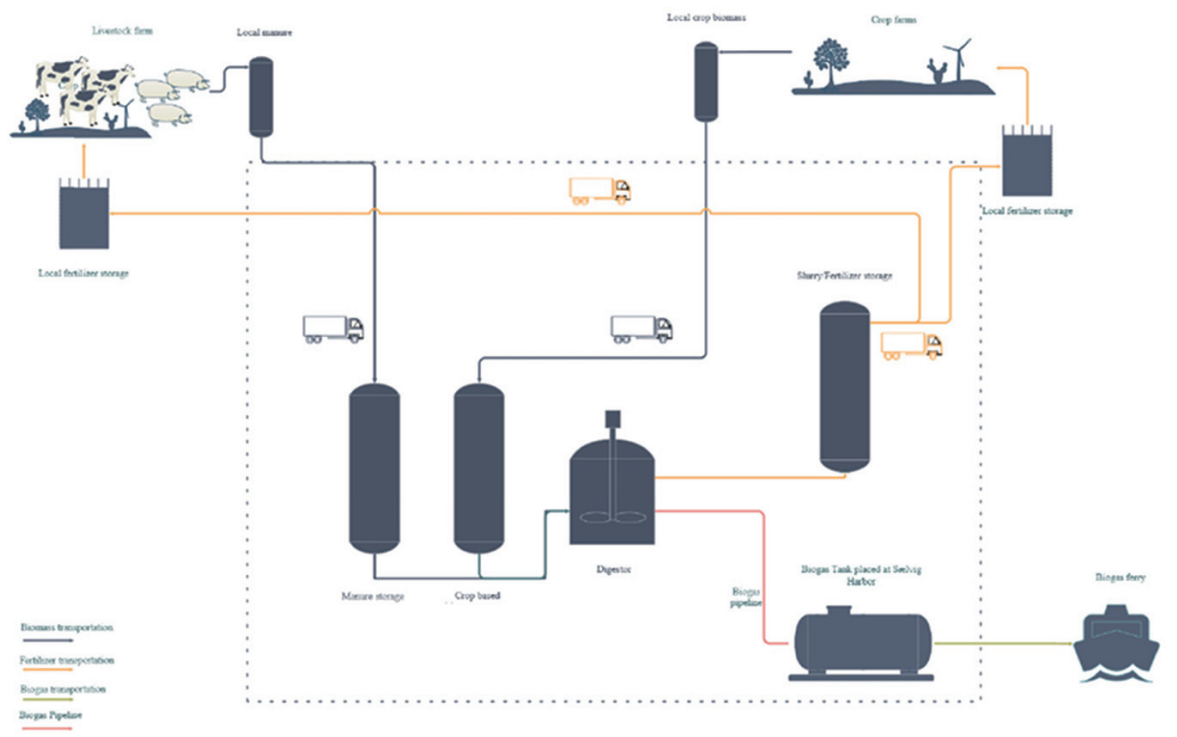

Figure 9 General production setup of biogas Sams $\emptyset$ - different perspectives of the Sams $\emptyset$ Biogas business setup related to network partners on the island of Sams $\varnothing$.

In addition to the manure types described in table above, there are also some production of manure from chickens, sheep, and equestrians, but the amount is negligible in the broader scope related to the Samsø Biogas plant (Sams $\varnothing$ Kommune 2015). In addition to the manure based biomass, there are a lot of crops which also can be used in the biogas production process. This is however also used for several other purposes, and even if it is energy crops produced for the specific purpose of biogas production it will still be competing for arable land in Sams $\varnothing$ on which other, potentially more valuable crops could be grown. This means that the availability of crop based biomass 
is highly dependent on the economic incentives for selling crops to the biogas plant - the Sams $\varnothing$ Biogas BMES compared to other BMES.

Biomass should preferably be stored at the farms until it is needed in the biogas production; however, manure has a shelf-life as it will start decomposing and producing methane from the beginning. The BM potential begins to shrink as it begins to send value out to the open air - another BMES. This means that to prevent this "waste" of value and even negative value creation (Climate polution). The biomass will need to be picked up across the different farms continuously, so that the decomposing and production of methane can be turned into value creation and captured to strengthen the BM. Crop based biomass can however be stored for longer without decomposing, either by drying it as with straw, or by producing silage from green and fresh biomass. This additionally increases the biogas potential of the biomass but needs some value capturing process and some value adding process. At the biogas plant two storage tanks for temporary holding should therefore be placed, one for manure and one for crop based biomass. This separation is needed to ensure the right live-mixture of feedstock for the biogas plant to optimize production and efficiency.

A major challenge to the Sams $\emptyset$ business and to establishing a Sams $\varnothing$ Biogas BMES is to actually get the biomass producers to prioritize to sell and deliver their biomass to the biogas plant. There are some benefits, however they might not outweigh the hassle of doing so. In order to simplify the process for the farmers, it is suggested that the biogas plant orchestrates a biomass pick-up service. This will eliminate the need for the farmer to spent useful time and resources on transport. Therefore there has to be innovated "relations" to the farmers from the Sams $\emptyset$ Biogas business and BMES and innovated some BM in the Sams $\varnothing$ BMES that can take care of the collecting and delivery functions.

\subsection{Fertilizer}

One of two primary end-products of the biogas production process is the fertilizer. The fertilizer is in essence the slurry left over when most of the feedstock has been converted into biogas. This slurry contains the same nutrients as it does when it is put into the digestor as it is chemical leftovers from the fermentation process producing biogas. The nutrients is in addition easier available to the plants which needs the fertilizer as it is no longer bound to dry matter to the same extent. A value add from the Sams $\varnothing$ Biogas business. This benefit is of utter importance to the Sams $\varnothing$ BMES as the increased quality 
of the fertilizer is one of the primary motivational factors for the farmers to engage in the Sams $\varnothing$ BMES ecosystem.

Once again, it is suggested that the biogas plant creates a fertilizer delivery service - a TO BE BM, to accompany the pick-up service BM. The argument here is the same as for the pick-up service BM in essence to reduce hassle for the farmers. This also results in the need for a holding tank for temporarily storing the fertilizer at the plant. In other words this adds on to the value chain functions that the Sams $\varnothing$ Biogas Business and BMES has to provide.

\subsection{Biogas}

The initiating factor for the generation of the Sams $\varnothing$ Biogas BMES was Sams $\varnothing$ Municipality, when they acquired the new gas driven ferry named Princess Isabella. It is currently running on natural gas and it refuels in Hou on the main land - Jutland - in other words at a different BMES.

A gas driven ferry enables a transformation towards $\mathrm{CO}_{2}$ neutral transport, if Sams $\emptyset$ succeeds to get a biogas plant and can produce the biomethane fuel themselves. However, as to the existing energy subsidy law of Denmark in 2016 the Biogas has to be filled into the existing gas infrastructure system before it can be financially supported by government's subsidies. Sams $\varnothing$ is an island - SAMS $\varnothing$ BMES - and therefore not hooked up to the existing national gas infrastructure - National BMES - on the main land. This leaves the Sams $\varnothing$ Biogas Business case and BMES in a rather odd situation. To optimize the

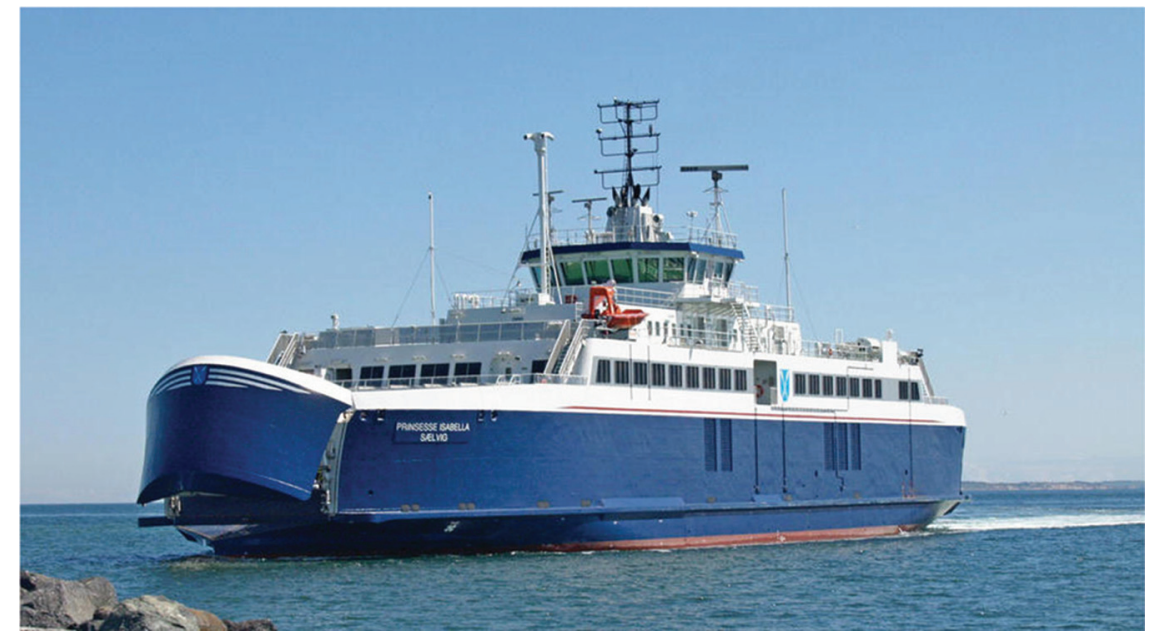

Figure 10 Samsø’s new gas driven ferry named Princess Isabella. 
Sams $\varnothing$ business economically - and hereby get the subsidy - the Sams $\varnothing$ Biogas business has store and transfer the gas via the ferry to the mainland, "inject" it to the national gas infrastructure - National GAS BMES, and withdraw the gas again. The gas has now been in physical contact - in relation - with the national gas infrastructure - National Gas BMES - and is now approved to get financially subsidized (add to the Sams $\varnothing$ value formula) and ready to return to the Samsø Biogas BMES.

If it is possible by the Sams $\varnothing$ Biogas business together with the participants in the Sams $\varnothing$ Biogas BMES to produce more biogas than what is necessary for the ferry, the possibility of expanding the use of biogas to e.g. local public transportation, heating, industrial process heat, etc. Hereby the Samsø Biogas BMES can increase.

The Ferry will need to refuel at the harbor in Sælvig, but it is not feasible to build the entire biogas plant on the harbor due to the available area, and the

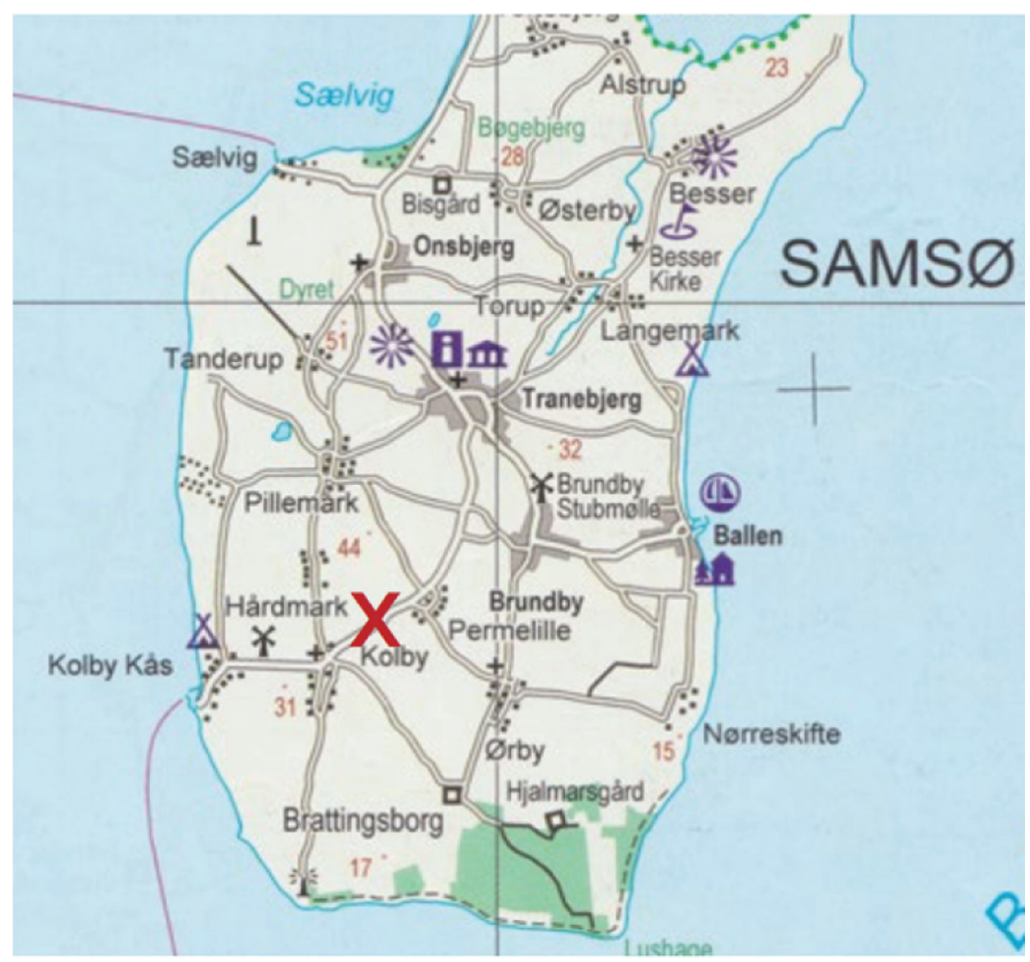

Figure 11 Biogas plant location proposal. 
vicinity to the inhabited areas. In this paper a specific placement for the biogas plant has not been finally decided since that depends on additional parameters not accounted for in this paper. However, there is a proposed placement in the southern part of the island. This placement is strategically chosen, since it is fairly nearby an essential partner in the BMES - Samsø Syltefabrik a factory that makes canned and glassed vegetables varying from sweet jams to sour pickles. The leftovers from those processes are nutritious waste water, that is essential for the biogas feedstock mixture - however, they varies due to the seasonal production changes.

It is clear that the biogas will somehow need to be transported from the biogas plant to the harbor site. It is suggested as one solutions that a biogas pipeline will run from the biogas plant to the harbor site at which it will pressurize in order to make it usable for the ferry. The alternative solution as mentioned before is to pressurize at the biogas plant, and transport it in tanks under pressure to the harbor site. But the long term cost of this is expected to be prohibitive. In other words the Sams $\varnothing$ Biogas Business and Sams $\varnothing$ Biogas BMES struggles with "being related" to other BMES and business models - to be able to create a sustainable business and BMES.

\subsection{Digital Communication}

In order for the engineering setup to function optimally, a consistent flow of data and valuable information between the Samsø biogas plant and other businesses' BMs e.g. the farmers, Sams $\varnothing$ Syltefabrik, Ferry business and so on is necessary. An online communication platform - TO BM - is proposed with the main purpose of informing about e.g.:

- Requested and pick-up of biomass

- Request and delivery of fertilizer

- Updated "pricelist" between business models

- Transaction balance between business models

A digital communication platform like this will in many way now create a digital relation between the different businesses' BMs within the Sams $\varnothing$ Biogas BMES, besides the more obvious physical relations in the form of manure, crops, waste water e.t.c.Discussion.

Putting the data from Sams $\emptyset$ Biogas Business and Sams $\emptyset$ Biogas BMES into the BMES framework shows the following figure. 


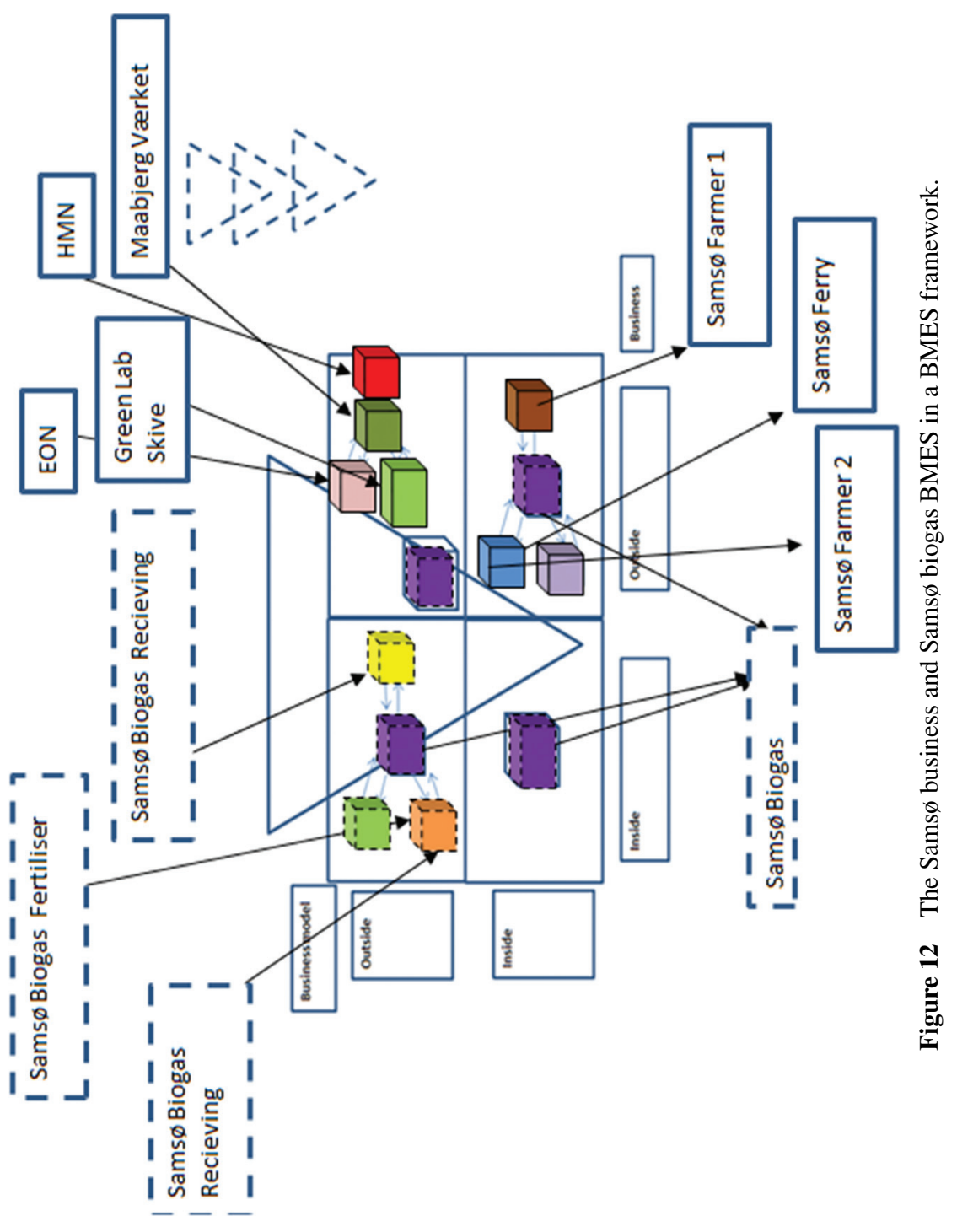


The example shows one TO BE BM from Sams $\varnothing$ Biogas Business. As Sams $\varnothing$ Biogas Business and its business models is not a reality yet - they are TO BE BM's - they are all marked as dotted line business model cubes both in quadrant 1 and 2. In quadrant 3 Samsø Biogas BM is a TO BE BM but all the other BM's are marked with full line as they are already operating business models but they are not yet related to Sams $\varnothing$ Biogas BM's except on a conceptual basis. Sams $\varnothing$ Biogas Business is at the moment trying to build up the relations so that when Samsø Biogas Business are ready to operate then it can become a full line business with established relations to the other network partners BM's. In quadrant 4 Samsø Biogas Business and the Biogas BM is not related to Biogas Business network at the mainland in Denmark.

The Sams $\varnothing$ Biogas BMES and Sams $\varnothing$ Biogas Business can be valued by a shared value process (Porter 2015) established. This is what the project management at Samsø Biogas Business is trying to innovation via engaging the inhabitants and businesses in several BMI process at the Island.

\section{Conclusion}

The BMES study shows a TO BE Sams $\varnothing$ Biogas BMES, Business and its business models in relation to existing Biogas BMES and its businesses business models. As argued Sams $\emptyset$ Biogas BMES and business cannot remain and "BMES Island" and "Business Island" because it will need to relate to other BMES and Businesses BM's to be able to establish the BMES and Business. Further if Sams $\varnothing$ Biogas BMES and Sams $\emptyset$ Biogas Business are not able to successfully establish these relations both will either have a very difficult venue and not even be able to establish a sustainable BMES and Business. One thing that could turn around the previous mentioned prediction and terms would be the establishment of change subsidiary conditions. This will however be at the minister of energy and the government level to decide.

\section{Further Research}

The research group will continue to follow the Samsø Biogas BMES and Sams $\varnothing$ Biogas Business together with the Green Lab Skive Biogas Business through the EU funded Biogas 2020 project - www.biogas2020.org through 2016-2018. 


\section{References}

[1] Amit, R., and Zott, G. (2001). Value creation in e-business. Strat. Manage. J. 22, 493-520.

[2] Molino, A., Nanna, F., Ding, Y., Bikson, B., and Braccio, G. (2013). Biomethane production by anaerobic digestion of organic waste. Fuel, 103, 1003-1009.

[3] Carroll, A. B. (1991). "The pyramid of corporate social responsibility: toward the moral management of organizational stakeholders," in Business Horizons. Netherlands: Elsevier.

[4] Carroll, A. B. and Shabana, K. M. (2010). The business case for corporate social responsibility: a review of concepts, research and practice. Int. J. Manage. Rev. doi: 10.1111/j.1468-2370.2009.00275.x

[5] Chesbrough, H. (2002). The role of the business model in capturing value from innovation: evidence from xerox corporation's technology spin-off companies." Ind. Corp. Change 11, 529-555.

[6] Chesbrough, H. W. (2006). Open Business Models: How to Thrive in the New Innovation Landscape. Boston, Mass: Harvard Business School Press.

[7] Christensen, C. M., and Raynor, M. E. (2003) The Innovator's Solution: Creating and Sustaining Successful Growth. Boston: Harvard Business School Press.

[8] Govindarajan, V., and Trimble, C. (2005). Building breakthrough businesses within established organizations. Harvard Bus. Rev.

[9] IEA Bioenergy. (2012). Quality Management of Digestate from Biogas Plants used as Fertilizer. Berlin: IEA Bioenergy.

[10] Kotler, P (1984) Principles of Marketing. Upper Saddle River, NJ: Prentice Hall.

[11] Lantz, M., Svensson, M., Björnsson, L., and Börjesson, P. (2007). The prospects for an expansion of biogas systems in Sweden - incentives, barriers and potentials. Energy Policy, 35, 1830-1843.

[12] Lindgren, P., Rasmusssen, O. H., Poulsen, H., Man-Sze, L. I., Hinchley, A., Martin, A., et al. (2013). Open business model innovation in healthcare sector. J. Multi Bus. Model Innovat.

[13] Lindgren, P., Rasmussen, O. H., and Saghaug, K. F. (2013). Business models relations to Intellectual Capital - How to release Intellectual Capital from business BM's relations," in IFKAD Conference Zagreb Croatia Conference Proceedings. 
[14] Lindgren, P., and Abdullah, M. A. (2013). Conceptualizing strategic business model innovation leadership for business survival and business model innovation excellence. J Multi Bus. Model Innovat. Technol. $1,115-134$.

[15] Lindgren, P., and Rasmussen, O. H. (2016). The Business Model Eco - System. J. Multi Bus. Model Innovat.

[16] Lindgren, P., Yariv, T., and Harry, B. (2010). From single firm to networkbased business model innovation. Int. J Entrepreneurship Innovat. Manage. 12, 122.

[17] Lindgren, P., Yariv, T., and Harry, B. (2010) "A Futuristic Outlook on Business Models and Business Model Innovation in a Future Green Society," in Wireless Personal Multimedia Communications Symposia Proceedings, August 10, 2010, 23.

[18] Lindgren, P. (2016). The business model ecosystem. J. Multi Bus. Model Innovat. Technol.

[19] Markides C. and Charitou, C. (2004). Competing dual business models: a contingency approach2. Acad. Manage. Execut. 18, 22-36.

[20] Markides, C. (2008). Game-changing strategies: how to create new market space in established industries by breaking the rules, JosseyBass: Wiley.

[21] Mazza, L., and Tucci, C. L. (2013). "Business Model Innovation," in the Oxford Handbook of Innovation Management, eds M. Dodgson, D. M. Gann, and N. Phillips, Chap. 21.

[22] Planenergi, 2015. Biogas til transport: Biomasse ressourcer til Biogasproduktion. Sams $\varnothing$ : Sams $\varnothing$ Kommune.

[23] Porter, M. E. (1985). Competitive advantage: creating and sustaining superior performance. Harvard Bus. Rev.

[24] Porter, M. E. (1998). Clusters and the new economics of competition. Harvard Bus. Rev., 76, 77.

[25] Porter, M. (2012). Shared values. Harvard Bus. Rev.

[26] Sams $\varnothing$, K. (2015). Biogas til Transport - Gennemførlighedsstudie af biogaskæde på Samsø.

[27] Teece, D. J. (2010). Business Models, Business Strategy and Innovation. Long Range Plan. 43:2-3, 172-194.

[28] Teece, D. J. (2011). Business models, business strategy and innovation. Long Range Plan. 43, 2-3.

[29] Weiland, P. (2010). Biogas production: current state and perspectives. Appl. Microbiol. Biotechnol. 85, 849-860. 
[30] Zott, C., and Amitt, R., and Mazza, L. (2010). The Business Model: Theoretical Roots, Recent Developments, and Future Research. Madrid, Spain: IESE Business School.

[31] Zott, C., Amit, R., and Massa, L. (2011). The business model: recent developments and future research. J. Manage. 37, 1019-1042.

\section{Biographies}

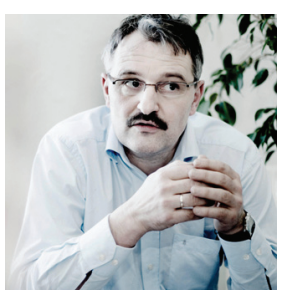

P. Lindgren Ph.D, holds a full Professorship in Multi business model and Technology innovation at Aarhus University - Business development and technology innovation and has researched and worked with network based high speed innovation since 2000. He has been head of Studies for Master in Engineering - Business Development and Technology at Aarhus University from 2014-2016. He is author to several articles and books about business model innovation in networks and Emerging Business Models. He has been researcher at Politechnico di Milano in Italy (2002/03), Stanford University, USA (2010/11), University Tor Vergata, Italy and has in the time period 2007-2010 been the founder and Center Manager of International Center for Innovation www.ici.aau.dk at Aalborg University. He works today as researcher in many different multi business model and technology innovations projects and knowledge networks among others E100 http://www.entovation.com/kleadmap/, Stanford University project Peace Innovation Lab http://captology.stanford.edu/projects/peace-innovation.html, The Nordic Women in business project - www.womeninbusiness.dk/, The Center for TeleInFrastruktur (CTIF) at Aalborg University www.ctif.aau.dk, EU FP7 project about "multi business model innovation in the clouds" www.Neffics.eu. He is co-author to several books. He has an entrepreneurial and interdisciplinary approach to research and has initiated several Danish and International research programmes. He is founder of the MBIT lab and is cofounder of CTIF Global Capsule. 
His research interests are multi business model and technology innovation in interdisciplinary networks, multi business model typologies, sensing and persuasive business models.

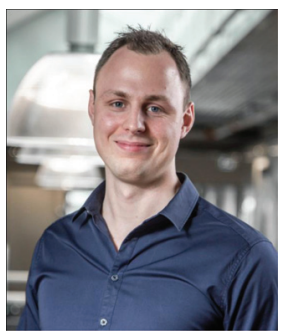

J. Bandsholm is a Scientific Assistent at the Department of Business Development and Innovation at Aarhus University. He holds a M.Sc. in Technology-Based Business Development and has interests in the scientific fields of innovation management, renewable energy and business model innovation. He puts an honor in working in tight collaboration with both public- and private sectors to get to understand and enhance their performance and introducing a new way of approaching innovation - Business Model Innovation. He is currently occupied with his attendance in the nordic Biogas2020 project, where he does different variations of business model innovation, such as network-based business model innovation between multiple partners, networks and ecosystems. 